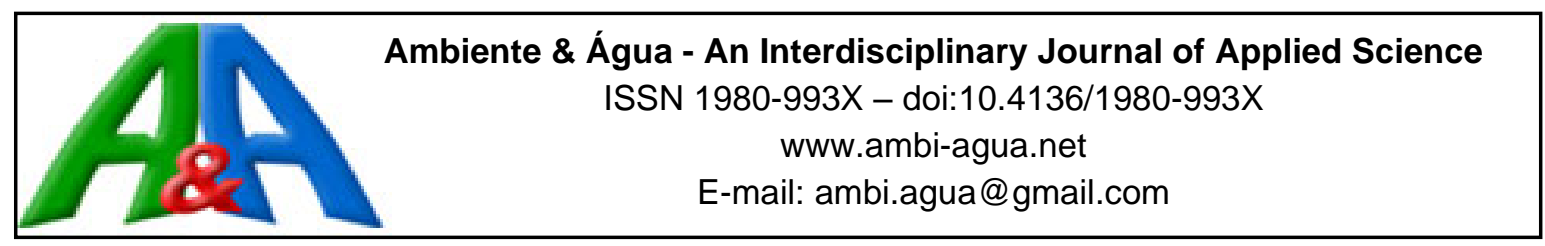

\title{
Effects on circulation and water renewal due to the variations in the river flow and the wind in a Brazilian estuary lagoon complex
}

\author{
ARTICLES doi:10.4136/ambi-agua.2600
}

Received: 16 Jun. 2020; Accepted: 26 Feb. 2021

\section{Cynara de Lourdes da Nóbrega Cunha ${ }^{*}{ }^{*}$; Ada Cristina Scudelari ${ }^{\circledR}$; Danilo de Oliveira Sant'Ana ${ }^{1}$; Teresa Elane Bezerra Luz ${ }^{2}$; Mariana Kummer da Rocha Pinheiro ${ }^{2}$}

\footnotetext{
${ }^{1}$ Departamento de Engenharia Ambiental. Universidade Federal do Paraná (UFPR), Avenida Coronel Francisco Heráclito dos Santos, no 100, CEP: 81530-000, Curitiba, PR, Brazil. E-mail: rgdanilooliveira@gmail.com

${ }^{2}$ Laboratório de Geotecnologias Aplicadas, Modelagens Costeira e Oceânica (GNOMO). Departamento de Engenharia Civil. Universidade Federal do Rio Grande do Norte (UFRN), Campus Universitário, s/n, CEP: 59078-970, Natal, RN, Brazil.E-mail: adaufrn@gmail.com, elanebluz30@gmail.com, marianakummer1@gmail.com

*Corresponding author. E-mail: cynara@ufpr.br
}

\begin{abstract}
The Mundaú-Manguaba Estuary Lagoon Complex is located on the coast of Alagoas state in Northeastern Brazil, and consists of two shallow lagoons, Mundaú and Manguaba, that form a system of choked lagoons which are connected to the Atlantic Ocean by a series of narrow channels with a single outlet which dynamically alters its position. This study uses the Hydrodynamic Environmental System, SisBaHiA® to investigate how variations in river discharge and wind influence hydrodynamic circulation, water renewal, salinity and temperature in the lagoons. The free surface positions, obtained by model, were compared with the free surface positions measured at two points of the complex, showing good agreement. The analyses were carried out for dry and wet seasons and extreme events with very high freshwater discharge. The channel system of the lagoons is an efficient filter in reducing tidal variability inside the lagoons. The tidal ranges in the Manguaba and Mundaú Lagoons are 90\% and 80\% lower, respectively, as compared with the values in the open boundary. The residence time calculated varied between 11 and 365 days and between 2 and 180 days for the Manguaba and Mundaú Lagoons, respectively, making it possible to identify possible stagnation areas. The results from the salt and heat transport model show a prolonged period with low salt concentrations and slow salinity recovery after the rainy season; the water temperature in the lagoons shows little spatial and temporal variation.
\end{abstract}

Keywords: hydrodynamic circulation, Mundaú/Manguaba lagoon estuary complex, residence time.

\section{Efeito na circulação e na renovação das águas em um complexo estuarino lagunar brasileiro, devido às variações do aporte fluvial e do vento}

\section{RESUMO}

O Complexo Estuarino Lagunar Mundaú-Manguaba está localizado no litoral do estado de Alagoas, no nordeste do Brasil, é formado por duas lagunas rasas, Mundaú e Manguaba, que 
constituem um sistema de lagunas sufocadas, conectadas com o oceano Atlântico por um conjunto de canais estreitos com uma única saída, que altera a sua posição dinamicamente. Este trabalho investiga como as variações do aporte fluvial e do vento influenciam a circulação hidrodinâmica, a renovação das águas, a salinidade e a temperatura nas lagunas usando o Sistema de Hidrodinâmica Ambiental computacional, SisBaHiA ${ }^{\circledR}$. Os valores da posição da superfície livre obtidos pelo modelo foram confrontados com dados medidos em dois pontos do complexo, apresentando uma boa concordância. As análises foram realizadas para as estações seca e chuvosa e para um evento extremo, com vazões dos rios muito elevadas. $\mathrm{O}$ sistema de canais das lagunas é um filtro eficiente na redução os efeitos da maré nas lagunas. Dentro das Lagunas de Manguaba e Mundaú, as amplitudes da maré são reduzidas em cerca de $90 \%$ e $80 \%$, respectivamente, em comparação com a fronteira aberta. O tempo de residência calculado variou entre 11 e 365 dias para a laguna Manguaba e entre 2 e 180 dias para Mundaú, permitindo identificar possíveis áreas de estagnação. Os resultados do modelo de transporte de sal e calor mostram um prolongado período com baixas concentrações de salinidade e uma lenta recuperação dos valores de salinidade após o período chuvoso; a temperatura da água nas lagunas apresenta pouca variação espacial e temporal.

Palavras-chave: circulação hidrodinâmica, complexo estuarino lagunar Mundaú/Manguaba, tempo de residência.

\section{INTRODUCTION}

Coastal lagoons, located mainly in tropical and subtropical regions, are driven by river flow, wind and, to a lesser degree, tides (Miranda et al., 2002). The Mundaú/Manguaba Lagoon Estuary Complex (CELMM), located on the coast of Alagoas state between 9 $35^{\prime} \mathrm{S}$ and $9^{\circ} 46^{\prime} \mathrm{S}$ and $35^{\circ} 43^{\prime} \mathrm{W}$ and $35^{\circ} 58^{\prime} \mathrm{W}$, is formed by the Mundaú and Manguaba Lagoons, comprising an area of $126 \mathrm{~km}^{2}$, and consists of a system of choked coastal lagoons connected to the Atlantic Ocean by a series of narrow channels that cross a mangrove swamp, forming a single outlet, which dynamically changes its position (Figure 1). This series of channels is an efficient filter in reducing tidal variability inside the lagoons.

The CELMM is an important natural breeding ground for mollusks, crustaceans, and fish, thus making fishing an important economic activity, along with tourism. An important source of income and food for the population that inhabits the margins of Mundaú and Manguaba Lagoons is the sururú mussel (Mytella Charruana), a bivalve mollusk that can be found in estuarine environments. In 2013, 1500 metric tons were harvested from the lagoons, far below the 5000 caught annually in the 1980s, as reported by Pereira-Barros (1987). According to Silva (1994), the sururú mussel is present in approximately $15 \%$ of the complex $\left(54 \mathrm{~km}^{2}\right)$, reaching a maximum density of $1770 \mathrm{ind} / \mathrm{m}^{2}$. According to Teixeira and Sá (1998), salinity is the most important regulator of the distribution and abundance of macro crustaceans in the CELMM, in addition to controlling the distribution of several fish species. The ideal salinity for sururú mussel harvesting is between 29.0 and 33.0, but laboratory experiments showed that the sururú withstood salinity of 12.0 during the rainy season (Pereira-Barros, 1987). Oliveira and Kjerfve (1993) reported that the sururú mussel cannot survive salinity below 2.0 for more than seven days. Consequently, knowledge of spatial and temporal variations in salinity levels is essential to managing sururú mussel harvesting.

The increasing amount of untreated domestic sewage and the declining salinity in the lagoons account for the drop in the sururú mussel production. The CELMM receives sewage waste from approximately 300,000 inhabitants of the metropolitan region of Maceió and seven neighboring cities, mainly on the left margin of the Mundaú Lagoon. Only 26\% of this sewage is collected and $4.5 \%$ treated; the rest is discarded directly into the lagoons without any treatment whatsoever (ANA, 2006). 

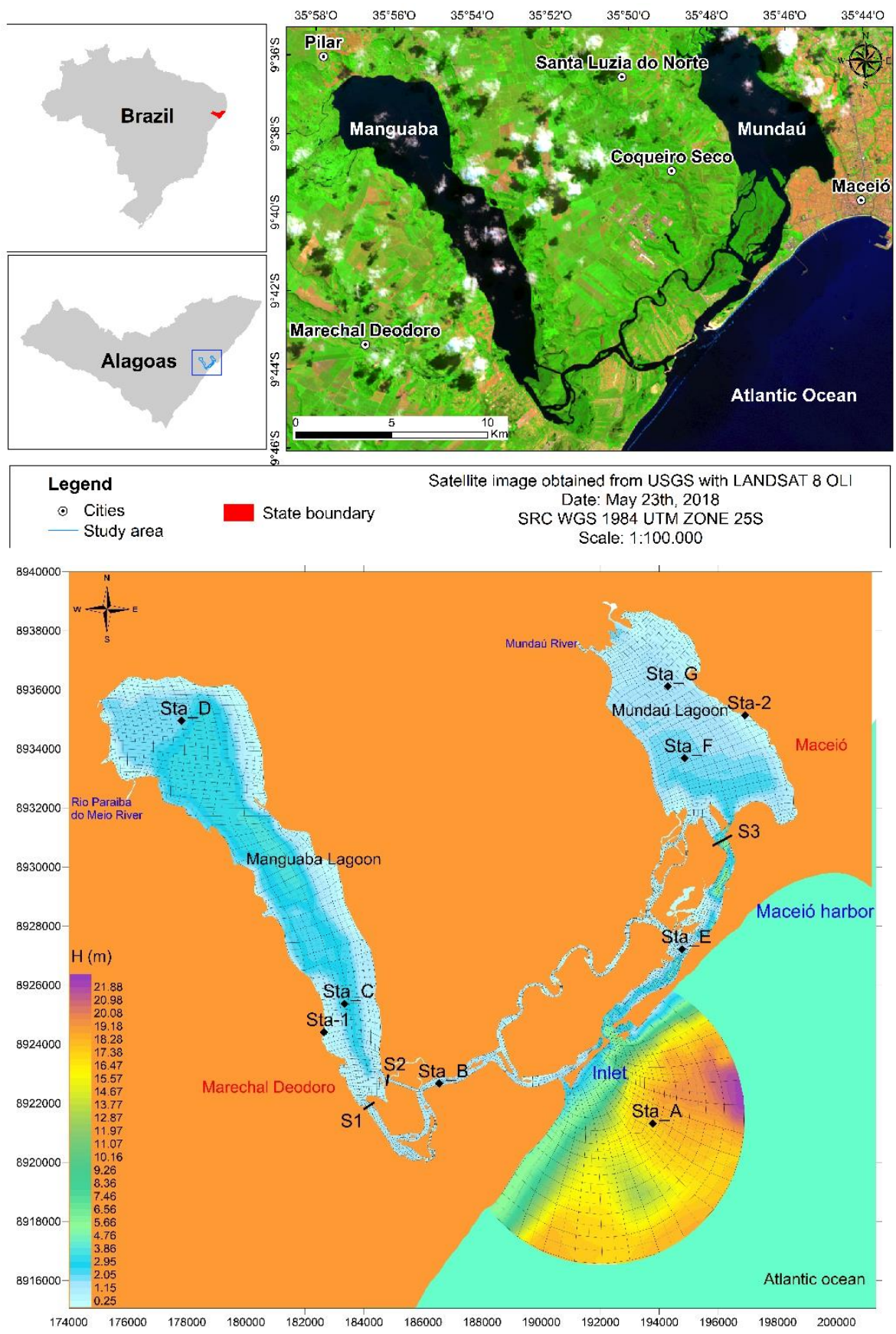

Figure 1. Mundaú-Manguaba Lagoon Estuary Complex (CELMM) in Alagoas state, Brazil, showing the port region and mouth, modeling domain, bottom topography, the discretizing mesh and the position of the 1488 finite elements and 6914 nodes and locations of stations Sta- 1 and Sta-2,where water levels were measured in 2014 , as well as the other stations (Sta A-G) and control sections S1, S2 and S3, where inlet and outlet volumes of the lagoons were calculated.

In the literature, there are several studies relating hydrodynamic circulation in the CELMM with water renewal rates and mixing. Oliveira and Kjerfve (1993) conducted an extensive study of the CELMM, assessing the hydrological characteristics, water level variations, absorption, and currents, as well as the temporal and spatial variations in salinity, based on a dataset obtained for the dry and wet seasons. In their analysis, they concluded that in Mundaú Lagoon 
currents and mixing are dominated by tides and modified by freshwater discharge, while in Manguaba Lagoon, tides are very small and wind force becomes dominant. Souza et al. (2004) developed a bi-dimensional hydrodynamic circulation model of the exchanges between oceanand lagoon-complex waters due to the bathymetric change in the channel. De Lima (2017) used bi-dimensional modeling and Mike 21 software to calculate the residence time of a pollutant, exemplified by a tracer inserted in the two lagoons. Brito et al. (2018) investigated the importance of tides in water exchanges in the Mundaú Lagoon for critical scenarios during the dry season, using the IPH-TRIM-3D- PCLake hydrodynamic module.

Numerical models have been used to understand the influence of the various forces in the hydrodynamic and in the spatial and temporal distributions of temperature, salinity and residence time distribution in lagoon systems. Kim and Park (2012) used a three-dimensional hydrodynamic model to study water and salt exchange between the Mobile Bay system and the Gulf of Mexico, showing that discharge and salt transport rates vary greatly in response to wind and river discharge. Li and Yao (2015) used a hydrodynamic model with transport and particletracking submodels to investigate the transport and spatial variation of the residence time in Poyang Lake, China. Panda et al. (2015) published a study describing a 2-D coupled model of hydrodynamic and water quality, developed to compute the hydrodynamic and the concentrations of the water quality parameters at different spatio-temporal scales to the largest brackish water coastal lagoon in Asia, namely the Chilika Lagoon in India. In the same lagoon, Mahanty et al. (2016) investigated hydrodynamics, spatio-temporal variability of temperature/salinity and residence time, combining data measurements and 2D hydrodynamicadvection/dispersion model. The authors calculated the residence time under different forces, such as tide, wind and freshwater discharge during the dry and wet periods. The results showed that tidal and river discharge significantly affect the spatial distribution of the residence time.

Water quality in the CELMM depends heavily on the volume of water exchanged between the lagoons and the adjacent coastal region. This process is related to circulation and determination of water renewal rates and mixing. In this respect, it is important to characterize the CELMM, considering the volume of water exchanged with the adjacent coastal region and the effects of mitigating tidal oscillation and currents inside the lagoons and connecting channels. The aim of this study is to broaden the understanding of the CELMM using computational modeling, which allows integrating spatially dispersed information and interpolating information for regions for which there are no available data, thereby making it easier to understand the dynamic processes in the CELMM.

With this purpose, this study employs the hydrodynamic and transport models of the SisBAHIA ${ }^{\circledR}$ (in Portuguese, Sistema Base de Hidrodinâmica Ambiental), in coupled form, to simulate flow, residence time, salinity and temperature in the CELMM. The advantage of coupling the models appears in the determination of the flow velocities and turbulence coefficients, which is done previously in the hydrodynamic model and can be used directly in the transport models.

Due to the importance of the wind and freshwater discharge in the circulation inside the lagoons, this study investigated how wind and river discharge variations affect the hydrodynamics of the CELMM, also showing the influence of these variations in water renewal processes, in spatial distributions of the salinity and in water temperature. Additionally, the study explored how the complex responds to extreme events, such as the high freshwater discharge that occurred in October 2014.

\section{MATERIALS AND METHODS}

As mentioned in the Introduction, the CELMM is formed by two lagoons and a series of mangrove channels that connect to the Atlantic Ocean through a single inlet. The bottom of the Mundaú Lagoon, with a depth between 1.5 and 3.5 m, covers an area of approximately 24.0 
$\mathrm{km}^{2}$, and contains shells, mollusks, carapaces and clay; the Manguaba Lagoon has an area of $42.0 \mathrm{~km}^{2}$ and presents maximum depth of $4.5 \mathrm{~m}$ (De Lima, 2017).

\subsection{Hydrological Characteristics}

The CELMM is located in Northeastern Brazil, which features a semiarid climate, with two well-defined seasons: dry and rainy. Average annual temperature and humidity are $25.5^{\circ} \mathrm{C}$ and around $80 \%$, respectively. The Mundaú and Paraíba do Meio Rivers are the primary sources of freshwater in the complex and contribute directly to the Mundaú and Manguaba Lagoons, respectively. The discharge data were provided by Brazilian National Water and Sanitation Agency (ANA, 2019) through the Hidroweb platform, for the period between 1974 and 2017 at stations $39770000\left(09^{\circ} 28^{\prime} 02.0^{\prime \prime} \mathrm{S}\right.$ and $\left.35^{\circ} 51^{\prime} 35.0^{\prime \prime} \mathrm{W}\right)$ and $39870000\left(09^{\circ} 30^{\prime} 24.0^{\prime \prime} \mathrm{S}\right.$ and $36^{\circ} 01^{\prime} 22.0^{\prime \prime} \mathrm{W}$ ) for the Mundaú and Paraíba do Meio Rivers (ANA, 2019), respectively. These data indicate that the months from October to March and from April to September constitute the dry and rainy seasons, respectively (Figure 2). In the two stations, the river discharges were indirectly determined by measuring the water stage $(\mathrm{h})$ and estimating the discharge $(\mathrm{Q})$ from a stage-discharge rating curve. The discharges measured at stations 39770000 and 39870000 in 2014, also shown in Figure 2, are very low between November and March and increase between May and September, corroborating historical measures. However, three atypical events occurred in May, August and October, with the Mandaú River reaching discharges of 456.56 $\mathrm{m}^{3} / \mathrm{s}$ and the Paraíba do Meio River reaching discharges of $489.75 \mathrm{~m}^{3} / \mathrm{s}$ on October $7,2014$. These events likely influenced hydrodynamic circulation in the lagoons and the turnover processes of the system. Thus, average discharges in 2014 differed from historical levels, exhibiting large fluctuations, primarily in the rainy season, while the differences in the dry season were not significant.

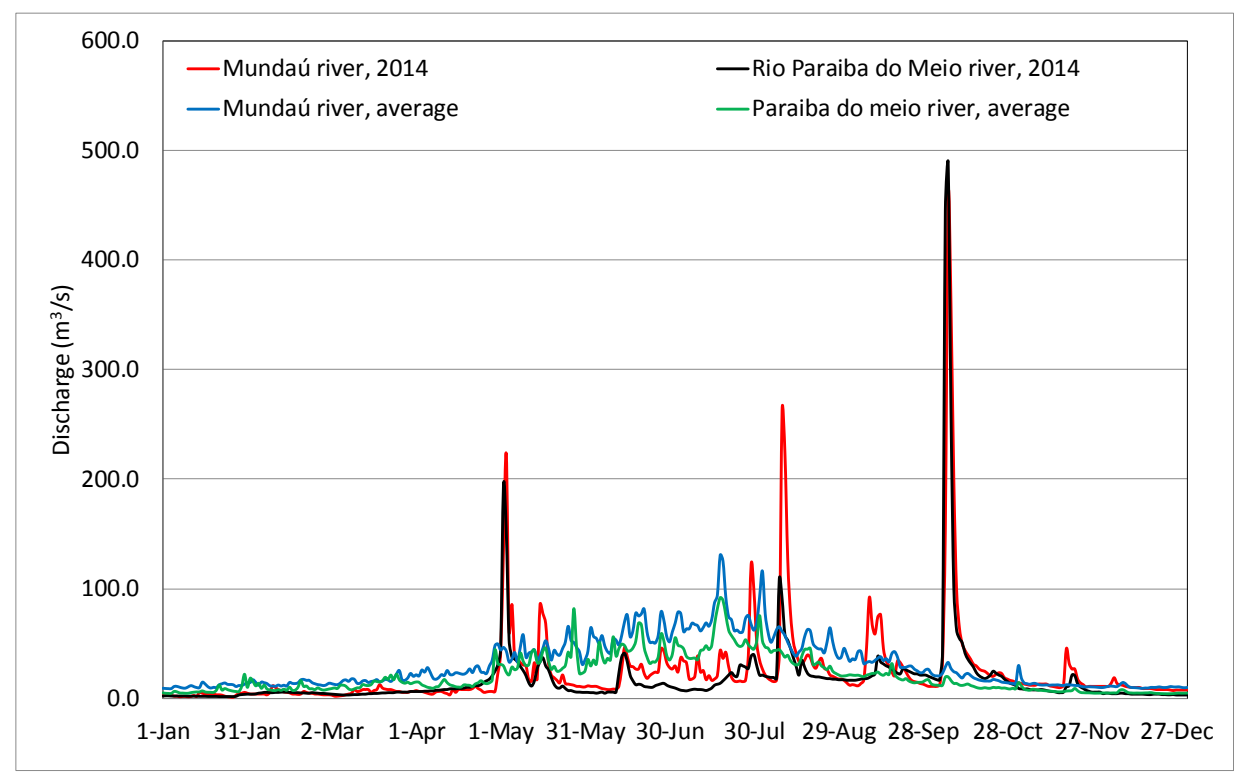

Figure 2. Average discharge of the Mundaú and Paraíba do Meio Rivers, in $\mathrm{m}^{3} / \mathrm{s}$, between 1974 and 2017 and for 2014, at stations 39770000 (Mundaú River) and 39870000 (Paraíba do Meio River).

\subsection{Wind characteristics}

In the dry season, the wind forces become dominant in hydrodynamic circulation and mixing in the CELMM, mainly in Manguaba Lagoon, when the freshwater discharge is lower. Velocity and direction of the wind were measured hourly at the station located near the Mundaú Lagoon (Maceió-A303), with coordinates 9 $33^{\prime} 04.2^{\prime \prime} \mathrm{S}$ and 3546'12.7" W (INMET, 2019). Figure 3 shows the wind regime between 2003 and 2019 and for 2014. Between 2003 and 2019, 
the wind was from the East $19 \%$ of the time, with an average speed of $2.68 \mathrm{~m} / \mathrm{s}$. In 2014, it was also mainly from the East, with an average speed of $2.62 \mathrm{~m} / \mathrm{s}$. Considering only the dry season (January and February), the wind was from the East $41 \%$ of the time, with an average speed of $2.85 \mathrm{~m} / \mathrm{s}$ (maximum of $5.68 \mathrm{~m} / \mathrm{s}$ ), while in the rainy season (June and July) it was from the SouthEast $21 \%$ of the time, with an average speed of $2.25 \mathrm{~m} / \mathrm{s}$ (maximum of $4.63 \mathrm{~m} / \mathrm{s}$ ). Lagoon alignment shows that the SouthEast wind influences hydrodynamic circulation more than the East wind, which predominates in the dry season. The wind in 2014 was similar to the average and differences between the dry and rainy season are only in the direction, with very similar velocities. Figure 3 shows average hourly values for velocity and direction, measured at the Maceió A-303 station between 2003 and 2019. In the dry season, winds were more intense than in its rainy counterpart and a daily cycle was also observed, with an increase in velocity during the day and a decline at night. With respect to direction, an East wind $\left(90^{\circ}\right)$ prevailed in the dry season, also occurring between the NorthEast $\left(45^{\circ}\right)$ and SouthWest $\left(225^{\circ}\right)$, whereas a SouthEast wind prevailed $\left(135^{\circ}\right)$ in the rainy season, with a West wind also occurring $\left(270^{\circ}\right)$.
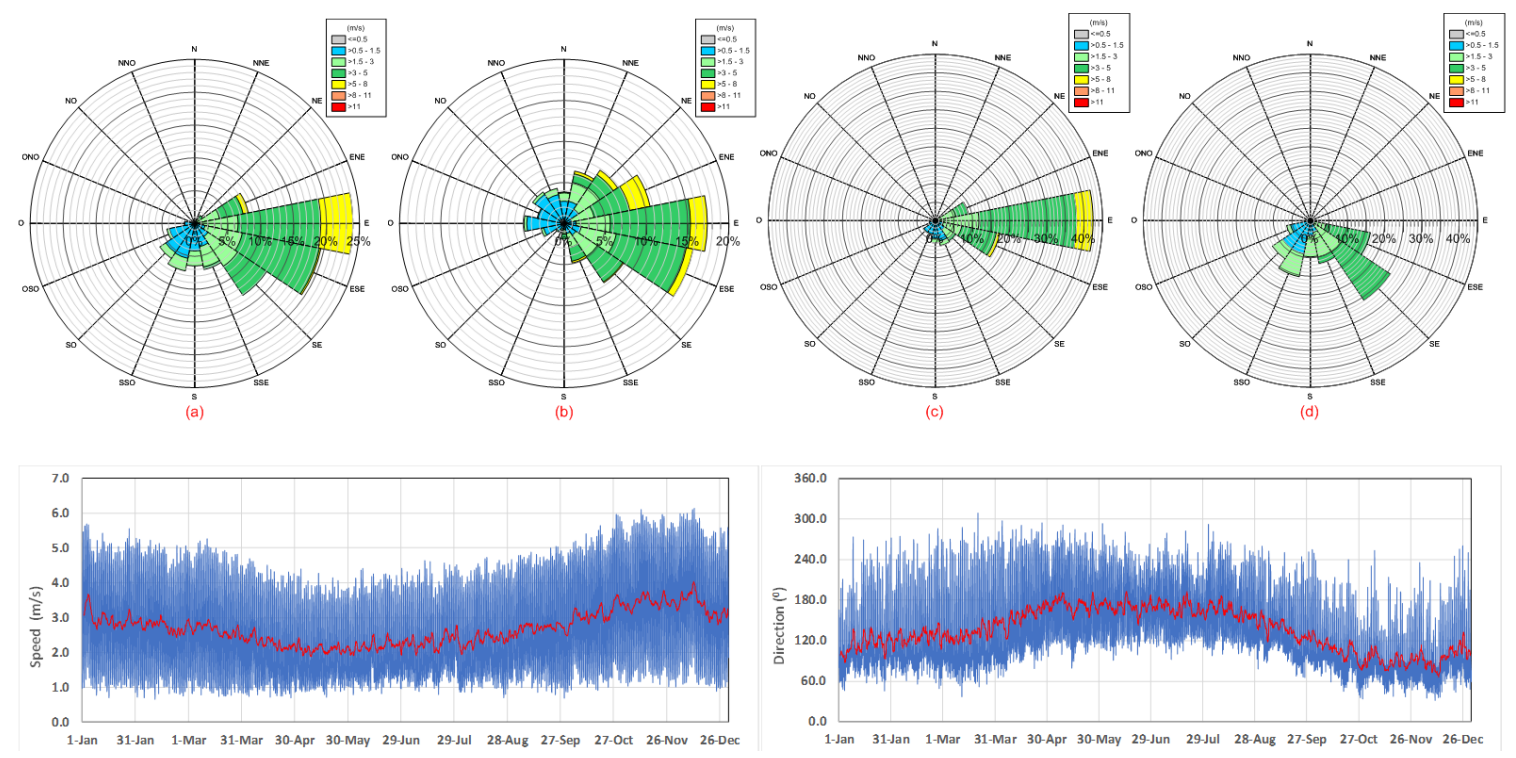

Figure 3. Wind regime between 2003 and 2019 (a), in 2014 (b), for January and February (c), June and July (d) between 2003 and 2019 and average daily wind speed and direction measured at the Maceió-A303 station between 2003 and 2019. The red curve corresponds to the 24-hour moving average.

\subsection{SisBaHiA ${ }^{\circledR}$}

The modeling system used here is SisBaHiA $^{\circledR}$ - Base System of Environmental Hydrodynamics, developed by COPPE/UFRJ. The computational simulations of this study employed the bi-dimensional hydrodynamic model, the water quality model (MQA) and the Lagrangian transport model implemented in SisBaHiA ${ }^{\circledR}$. The MQA is a Eulerian advectivediffusive transport model vertically integrated for non-conservative scales. The hydrodynamic model uses a second-order numerical scheme for temporal discretization and quadratic finite elements for spatial discretization. The wind fields and bottom friction varied dynamically in time and space and the turbulent stress is parameterized according to filtering techniques derived from the approach known as Large Eddy Simulation (LES). The MQA uses the same spatial grid applied for the hydrodynamic model and different time step lengths can be employed in analyses. The Lagrangian transport model is especially adequate for determination of residence time in natural water bodies, making it possible to obtain isoline maps of residence times in different sectors of water bodies with complex geometry (Rosman, 2019). This computational system has been successfully used in different studies (González-Gorbeña et al., 
2015; Cunha et al., 2018; Aguilera et al.; 2020).

Initially, the hydrodynamic model was calibrated with 10 days. Afterwards, simulations for different periods were carried out. Then, the Eulerian (MQA) and Lagrangian transport models were applied for different hydrodynamic scenarios. For additional information concerning model and equations, the reader is referred to Rosman (2019) and http://www.SisBaHiA.coppe.ufrj.br/.

\subsection{Hydrodynamic circulation model data}

The bathymetry of CELMM, presented in Figure 1, was obtained from DHN (Directory of Hydrography and Navigation) nautical chart no. 910 - Port of Maceió, scale 1:17500, and from databases of the National Water Agency, ANA, in 2012 and obtained by Petróleo Brasileiro S.A., PETROBRAS in 2011. The mesh used to discretize the domain exhibits complex geometry and contains 1488 quadrilateral elements and 6914 nodes (Figure 1), with the presence of narrow channels that link the lagoons to the adjacent coastal region. The time interval used in hydrodynamic circulation simulations was 10 seconds, which corresponds to an average Courant number of 0.65 . The model for CELMM had a warming-up period of two tide cycles to minimize any influence from the initial conditions on the results obtained. In the sea level boundary condition, the free surface position values are prescribed by applying the astronomical tide curve, obtained from 19 harmonic constituents established for the Maceió Harbor, with an average level ( $\left.\mathrm{z}_{0}\right)$ of $1.08 \mathrm{~m}$ (FEMAR, 2009). Figure 4 shows the tide curve between 01/01/2014 and 12/31/2014. The CELMM exhibits a semidiurnal tidal regime, with a maximum range of $2.55 \mathrm{~m}$ and maximum tide height of $1.29 \mathrm{~m}$.

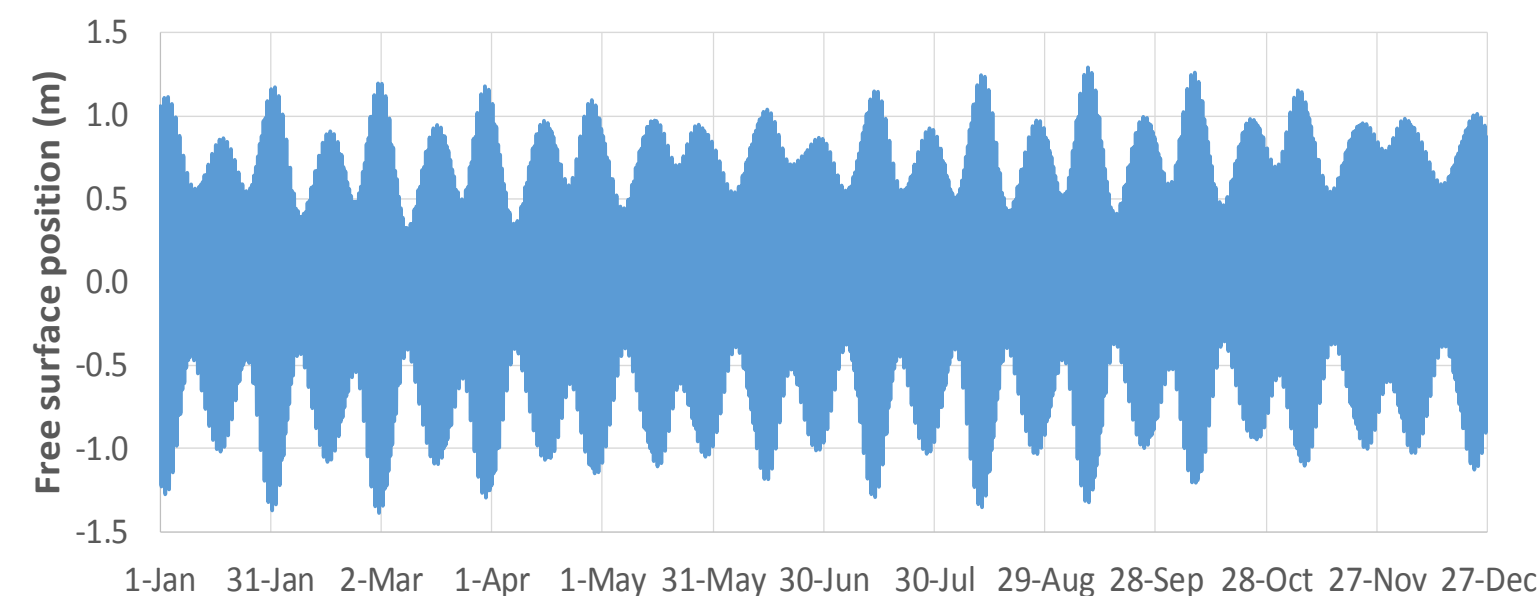

Figure 4. Sea level boundary condition, obtained from the harmonic constants provided by the DHN for the Maceió Harbor in 2014.

Except for the nodes corresponding to the rivers (Mundaú and Paraíba do Meio), all the boundary nodes were considered impermeable, with zero normal discharge. The wind is considered unsteady and spatially homogeneous. The bottom friction coefficient is established by the Chezy coefficient, which depends on the equivalent bottom roughness. The amplitudes of the equivalent bottom roughness, $\xi$, were obtained from Alves (2010). The Mundaú and Manguaba Lagoon beds are predominantly composed of clay $(\xi=0.005 \mathrm{~m})$ while middle sands are preponderant in the channels $(\xi=0.022 \mathrm{~m})$; coarse-grained sandbanks $(\xi=0.035 \mathrm{~m})$ are also found in the adjacent coastal region.

The calibration of the hydrodynamic model was performed for the year 2014. Measures were taken of the free surface position in the lagoons every 15 minutes between 02/16/2014 and 02/25/2014 (Brito et al., 2018); the sites are identified as stations Sta-1 and Sta-2 (Figure 1). In order to simulate hydrodynamic circulation, tide (Figure 4), wind (Figure 3) and freshwater discharge from 2014 (Figure 2) data were provided. Another hydrodynamic 
simulation in the CELMM was carried out using the tide curve for 2014 (Figure 4), average daily fresh water discharge between 1974 and 2017 (Figure 2) and average hourly wind between 2003 and 2019 (Figure 3). In the analyses conducted here, eight periods were considered to establish the different environmental conditions, which makes it possible to identify which of the effects of different forcing - tide, river discharge and wind - would have the greatest influence on hydrodynamic circulation and the water renewal process. Four periods were carried out with daily average of wind and river discharge data (periods $1,3,5$, and 7) and four periods take into account wind and river discharge data from 2014 (periods 2, 4, 6, and 8). Table 1 shows, in detail, the characteristics of eight periods. In order to investigate the influence of high river discharge on the hydrodynamic circulation, the period between September and November 2014 was selected (period 8) and compared to period 7, which does not consider this discharge.

Table 1. Characteristics of eight periods used to define hydrodynamic circulation in the CELMM.

\begin{tabular}{ccc}
\hline Periods & Wind and water flow data & Simulation period \\
\hline 1 & Average & $01 / 01 / 2014$ to $31 / 12 / 2014-365$ days \\
2 & 2014 & $01 / 01 / 2014$ to $31 / 12 / 2014-365$ days \\
3 & Average & $01 / 01 / 2014$ to $03 / 02 / 2014-61$ days \\
4 & 2014 & $01 / 01 / 2014$ to $03 / 02 / 2014-61$ days \\
5 & Average & $06 / 01 / 2014$ to $07 / 31 / 2014-61$ days \\
6 & 2014 & $06 / 01 / 2014$ to $07 / 31 / 2014-61$ days \\
7 & Average & $09 / 16 / 2014$ to $11 / 15 / 2014-61$ days \\
8 & 2014 & $09 / 16 / 2014$ to $11 / 15 / 2014-61$ days \\
\hline
\end{tabular}

\subsection{Transport model data}

Salt and heat transport modeling in the CELMM was developed for the different hydrodynamic circulation periods using the MQA model of SisBaHiA ${ }^{\circledR}$. Along open boundaries, it is usual to neglect the diffusive fluxes; for this reason, the model computes the mass balance equation with no diffusive term. In the case of influx, salinity and temperature, their values are prescribed according to the HYCOM (HYbrid Coordinate Ocean Model) oceanographic model (Wallcraft et al., 2009). Figure 5 shows the values for 2014, which were used in the simulations of all the periods. For the land boundary, the average temperatures measured at stations 39770000 and 39870000 were used in the nodes corresponding to the rivers (Mundaú and Paraíba do Meio) (Figure 5). Salinity was considered null in the rivers. The other boundary nodes were considered impermeable, with zero normal flow. A 60-second time interval was used in the simulations and the MQA had a warming up period of ten tide cycles.
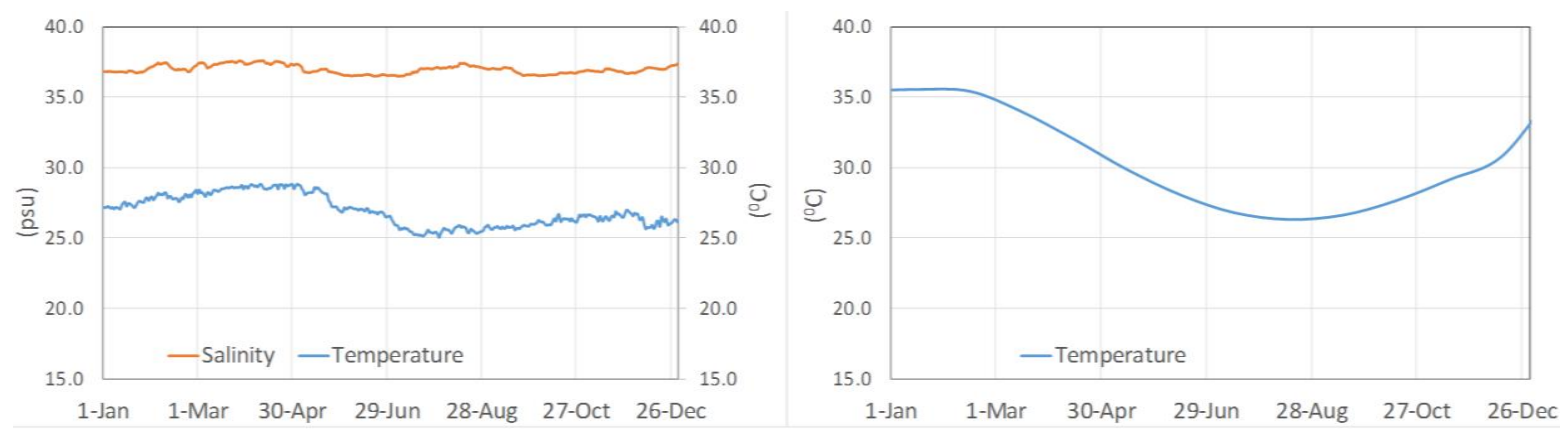

Figure 5. Salinity (psu) and temperature values $\left({ }^{\circ} \mathrm{C}\right)$ at the open boundary, obtained from the HYCOM model (left) and temperatures $\left({ }^{\circ} \mathrm{C}\right)$ for the Mundaú and Paraíba do Meio Rivers in 2014, obtained from the measurements at stations 39770000 and 39870000 (right). 


\subsection{Water renewal indicator: Residence time}

Residence time is traditionally defined as the average time a fluid particle remains in a compartment, and is usually calculated by the ratio between the volume of the compartment and residual flow through the compartments. The scale of residence time can be derived by calculating the average inflow and outflow volumes and determining the balance between the volumes that enter and leave the lagoons. The volumes were calculated using the results of the hydrodynamic model in three control sections: S1 and S2, 120m and $150 \mathrm{~m}$ wide, respectively, in Manguaba Lagoon, and one for the Mundaú Lagoon, S3, $380 \mathrm{~m}$ wide. Figure 1 shows the location of the sections. The residence time scale can be calculated as follows Equation 1:

$\operatorname{Tr}=\frac{V}{Q}=\frac{V}{(1-b) Q_{T}+Q_{R}}$

Where $V$ is the volume of the lagoons, $Q$ the volumetric flow, $Q_{T}$ and $Q_{R}$ are the tide and river flow, respectively, and $b$ is a factor for describing the water fraction that returns through the inflow, that is, during periods of flooding. Based on analysis of salinity data, Oliveira and Kjerfeve (1993) found $b=0.7$ for Mundaú Lagoon, that is, only $30 \%$ of "new" water originates in the ocean. This model considers the system in permanent regime, well mixed and with low freshwater discharge compared to the volume of the tidal prism. This concept is useful and adequate when the fluid mass in the compartment is well mixed. However, there is large spatial heterogeneity, with varied flow conditions in space and time in the compartments of natural water bodies. Due to the large spatial and temporal variation in natural water bodies, it seems to be more adequate to define a spatially variable residence time (RT) function for the characteristic flow conditions of different hydro-meteorological forces. In natural water bodies, the calculation of the spatially variable RT is only viable using computational modeling. The SisBaHiA ${ }^{\circledR}$ methodology, developed using the Lagrangian transport model, was adopted to calculate the spatial distribution of RT (Aguilera et al., 2020). In the present study, 5059 particles were initially released, then distributed into a $200 \times 200$-meter grid, in a 365-day simulation.

\section{RESULTS AND DISCUSSION}

\subsection{Hydrodynamic circulation model}

The results for the free surface position were validated by comparison with data measured at Sta-1 (Manguaba Lagoon) and Sta-2 (Mundaú Lagoon) (Brito et al., 2018). The two stations used to calibrate the model show good agreement with the phase of the tide, but differences in amplitude (Figure 6 ). The $\mathrm{R}^{2}$ (correlation coefficient) of the calibration was 0.84 and 0.65 for the Mundaú and Manguaba Lagoons, respectively. One possible cause for obtaining a lower value for $\mathrm{R}^{2}$ in Manguaba Lagoon is that the bathymetry used in the modeling is much older than the period for which these simulations were performed. It is evident in Manguaba Lagoon that the tidal ranges computed by the model were reduced. This behavior is common in choked lagoons due to the presence of a series of narrow channels that absorb the tidal wave. Problems in defining the geometry, bathymetry and bottom roughness of the channels may generate higher or lower absorption of the tidal wave. The correct characterization of these channels plays an essential role to ensure that the model is able to produce accurate results in the lagoons.

Table 2 shows the maximum tidal range $(\mathrm{m})$ and percentage in relation to the adjacent coastal region (Sta A) at the various stations for the different periods. At Sta E, located in the channel near the mouth, the maximum tidal range is lower, with values varying between 53 and $58 \%$ in relation to Sta A; Sta B shows a greater decline, between 18 and 35\%, indicating a severe head loss along the channels that link the Manguaba Lagoon to the ocean. The maximum tidal range at the entrance of the CELMM (Sta A), in 2014 (period 1), was equal to $2.68 \mathrm{~m}$, whereas in the Manguaba Lagoon (Sta D), it was equal to $0.51 \mathrm{~m}$ and, in the Mundaú Lagoon 
(Sta G), $0.72 \mathrm{~m}$, representing an average decline of 81 and $73 \%$ for the Manguaba and Mundaú Lagoons, respectively.

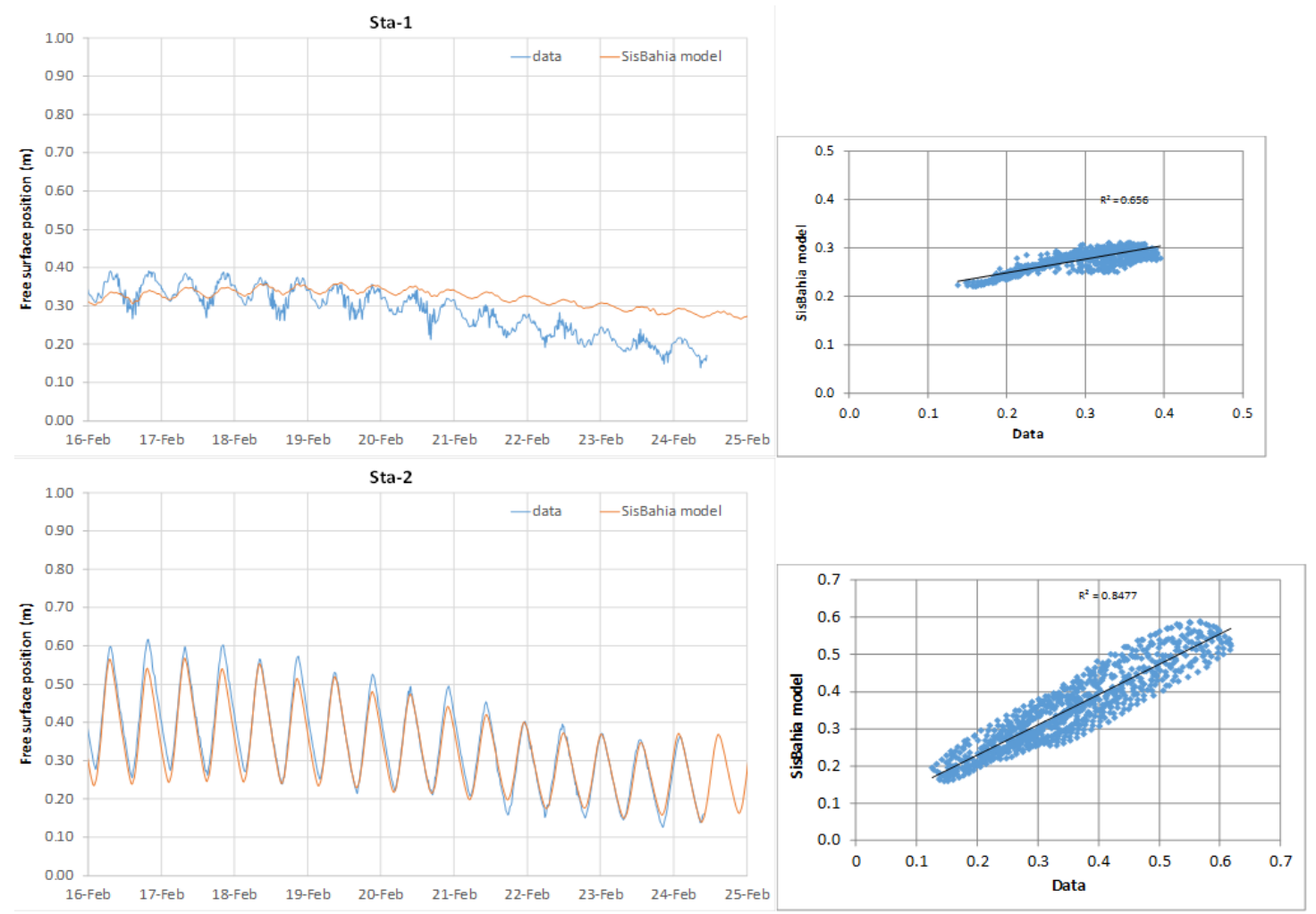

Figure 6. Results of the calibration of the hydrodynamic model. Free surface position at Manguaba (Sta-1) and Mundaú Lagoons (Sta-2). Measured and simulated free surface position dispersion at Sta-1 and Sta-2.

With respect to the different periods, in the dry season (P3 and P4) absorption was similar to that of the rainy periods (P5 and P6). However, a comparison of the two periods with different freshwater discharge (P7 and $\mathrm{P} 8)$ shows that the increased river discharge in period 8 decreased the absorption by up to 20\%, primarily in the Manguaba Lagoon; in the Mundaú Lagoon the decline was approximately $10 \%$. The increase in river discharge had little effect in the channels.

Harmonic analysis of the temporal series of the water level, with 15-minute intervals, at CELMM stations for period 1 in 2014 was conducted by applying SisBAHIA ${ }^{\circledR}$ (further details on harmonic analysis can be found in Rosman, 2019). The ranges of harmonic components at the stations were compared with the values obtained for the Maceió Harbor, considered as a boundary condition. The results demonstrate a predominance of the semidiurnal lunar $\left(\mathrm{M}_{2}\right)$ and solar $\left(\mathrm{S}_{2}\right)$ constituents, which together explain $65 \%$ of the total tidal range. In the Manguaba Lagoon (Sta $\mathrm{C}$ and D), $98 \%$ of the $\mathrm{M}_{2}$ and $\mathrm{S}_{2}$ amplitudes were absorbed, while in the Mundaú lagoon (Sta $\mathrm{F}$ and $\mathrm{G}$ ) the $\mathrm{M}_{2}$ and $\mathrm{S}_{2}$ amplitudes were $82 \%$ and $86 \%$ lower, respectively. Another two semidiurnal constituents $\left(\mathrm{N}_{2}\right.$ and $\left.\mathrm{K}_{2}\right)$, and the diurnal constituents $\left(\mathrm{Q}_{1}, \mathrm{O}_{1}\right.$ and $\left.\mathrm{K}_{1}\right)$ also exhibited absorption, with values ranging between $96 \%$ and $98 \%$ for the Manguaba Lagoon (Sta $\mathrm{C}$ and D), and $72 \%$ and $84 \%$ for Mundaú Lagoon (Sta F and G). The other 12 components explain a small portion of the tidal range (15\%). When the tidal wave spread to internal areas, the friction effect absorbed the tidal constituents differently and created new components, known as "shallow water constituents", generated by interactions due to friction and to other nonlinear effects, resulting in distortions of essential components, which may be amplified. The shallow water constituents $\left(\mathrm{M}_{4}\right.$ and $\left.\mathrm{MS}_{4}\right)$ were amplified in the channel as follows: $\mathrm{M}_{4}$ was amplified 3.33 times at Sta-B and 3.71 at Sta-E and $\mathrm{MS}_{4} 1.02$ times at Sta-B and 1.03 at Sta-E. 
Table 2. Maximum tidal range (MTR) and percentage (\%) in relation to Sta A at the various stations for the different periods.

\begin{tabular}{ccccccccccccccccc}
\hline & Sta_A & \multicolumn{2}{c}{ Sta_B } & \multicolumn{2}{c}{ Sta_C } & \multicolumn{2}{c}{ Sta_D } & \multicolumn{2}{c}{ Sta_E } & \multicolumn{2}{c}{ Sta_F } \\
\hline & MTR(m) & MTR(m) & $\%$ & MTR(m) & $\%$ & MTR $(m)$ & $\%$ & MTR(m) & $\%$ & MTR(m) & $\%$ & MTR(m) & $\%$ \\
\hline P1 & 2.68 & 0.75 & 27.9 & 0.51 & 18.9 & 0.51 & 19.1 & 1.48 & 55.1 & 0.71 & 26.5 & 0.72 & 26.7 \\
P2 & 2.68 & 1.02 & 38.1 & 0.82 & 30.9 & 0.83 & 31.0 & 1.56 & 58.3 & 0.98 & 36.5 & 0.99 & 36.8 \\
P3 & 2.58 & 0.62 & 23.9 & 0.27 & 10.5 & 0.28 & 10.6 & 1.39 & 53.9 & 0.59 & 22.8 & 0.60 & 23.1 \\
P4 & 2.58 & 0.61 & 23.5 & 0.21 & 8.2 & 0.24 & 9.1 & 1.39 & 53.8 & 0.59 & 22.7 & 0.60 & 23.1 \\
P5 & 2.44 & 0.46 & 18.9 & 0.26 & 10.6 & 0.26 & 10.7 & 1.32 & 53.9 & 0.53 & 21.6 & 0.54 & 21.9 \\
P6 & 2.44 & 0.49 & 20.0 & 0.23 & 9.4 & 0.24 & 9.6 & 1.31 & 53.6 & 0.53 & 21.58 & 0.54 & 22.0 \\
P7 & 2.47 & 0.56 & 22.7 & 0.23 & 9.2 & 0.24 & 9.6 & 1.35 & 54.9 & 0.62 & 25.3 & 0.63 & 25.6 \\
P8 & 2.47 & 0.87 & 35.2 & 0.69 & 28.1 & 0.71 & 28.6 & 1.45 & 58.6 & 0.89 & 36.1 & 0.90 & 36.4 \\
\hline
\end{tabular}

With respect to absorption in the Manguaba and Mundaú Lagoons, the tidal range was around 90 and $80 \%$ lower, respectively, when compared to the adjacent coastal region. In the channel that links the Mundaú Lagoon to the adjacent coastal region, the maximum tidal wave range was around 45\% lower, and in the channels that connect the Manguaba Lagoon the decline was greater, ranging between $65 \%$ and $82 \%$. The average level increased inside the lagoon as a function of freshwater discharge: values were lower in the dry periods with the greatest increases in average lagoon level occurring in the rainy season.

Considering the dominance of $\mathrm{M}_{2}$, tidal wave asymmetry can be analyzed using the relation between the amplitude and phase of $\mathrm{M}_{2}$ and $\mathrm{M}_{4}$, the first harmonic of $\mathbf{M}_{2}$, which is highly significant in tidal wave distortion in estuarine systems. The amplitude ratios between $\mathrm{M}_{2}$ and $\mathrm{M}_{4}$ were calculated for all the stations (Table 3), capable of quantifying the degree of distortion, and the phases measured between $\mathrm{M}_{4} / \mathrm{M}_{2}$ to determine the direction of distortion, with a dominance of flooding or ebb currents. The values found show increased distortion in the system, with values in the Mundaú Lagoon (Sta F and G) higher than those found in the channel (Sta E). The connecting channel between the Manguaba Lagoon and the adjacent coastal region (Sta B) demonstrated greater distortion. With respect to the phases between $\mathrm{M}_{4} / \mathrm{M}_{2}$, the values ranged between $25.19^{\circ}$ and $105.79^{\circ}$, with flood dominant, where floods have short duration and high speeds. This lag caused more prolonged ebb then flooding and the asymmetry between flooding and ebb currents was greater in the channel and significant in the lagoons. In general, establishing tidal wave asymmetries is important in terms of water renewal rates.

Rev. Ambient. Água vol. 16 n. 2, e2600 - Taubaté 2021 
Table 3. Amplitude $\left(\mathrm{R}_{\mathrm{M} 4 / \mathrm{M} 2}\right)$ and relative phase ratios between $\mathrm{M}_{4} / \mathrm{M}_{2}$ $\left(\Delta_{\mathrm{M} 4 / \mathrm{M} 2}\right)$ for period 1 .

\begin{tabular}{cccccccc}
\hline & Sta A & Sta B & Sta C & Sta D & Sta E & Sta F & Sta G \\
\hline $\mathrm{R}_{\mathrm{M} 4 / \mathrm{M} 2}$ & 0.012 & 0.264 & 0.119 & 0.162 & 0.077 & 0.126 & 0.131 \\
$\Delta_{\mathrm{M} 4 / \mathrm{M} 2}\left(^{\circ}\right)$ & 39.91 & 25.19 & 105.79 & 100.51 & 44.16 & 78.16 & 78.46 \\
\hline
\end{tabular}

\subsection{Water renewal rates}

The residence time scale was assessed for the different periods. Table 4 shows mean freshwater discharges from the tributaries to the lagoons, average inflow and outflow volumes in the sections, volume variations, lagoon volumes and residence time scale, considering the tidal period of $12.42 \mathrm{~h}$. The convention normally used for estuaries and lagoons was applied as follows: positive volumes indicate a flow towards the outflow of the lagoon, i.e., an ebb current, and negative volumes indicate an inflow, or flooding. In the two lagoons and during nearly all the periods there was a trend towards ebb currents, with lower inflow than outflow volumes. Only in the very dry period (period 4), when the Paraíba do Meio River discharge is extremely low, a system inversion occurs, with a tendency for the Manguaba Lagoon to flood. Major volume differences are observed in both lagoons in periods 5 and 8, corresponding to the rainy season and the extreme events, with high freshwater discharge, respectively. The smallest differences occurred in periods 3 and 4, corresponding to the dry periods. Thus, the residence time scale followed the same behavior, with the highest values occurring in the dry periods and the lowest in the rainy season.

The water mass exchanges in the Manguaba Lagoon are less efficient, reflecting the lower discharge and higher volume of the Lagoon. As such, the residence time scale for the Manguaba Lagoon was always much higher than that of the Mundaú Lagoon, varying between 23.81 and 123.26 days for the Manguaba Lagoon and between 6.02 and 18.19 days for the Mundaú Lagoon. Oliveira and Kjerfeve, 1993, found a 16- and 36-day turnover time for the Mundaú and Manguaba Lagoons, respectively; Brito et al. (2018), found a turnover time of 12.6 and 5.7 days for neap and spring cycles, respectively, in the Mundaú Lagoon. The effect of the high freshwater discharge that occurred in period 8 decreased the residence time scale in the two lagoons, showing that river flow has an important effect on water mass exchanges between the lagoons and the adjacent coastal region. 
Table 4. Mean discharges for Mundaú and Paraíba do Meio Rivers, inflow and outflow volumes, variation between inlet and outlet volumes, lagoon volumes and residence time scale of the Mundaú Lagoon and Manguaba Lagoon for the different periods.

\begin{tabular}{|c|c|c|c|c|c|c|c|c|c|}
\hline & & $\mathrm{P} 1$ & $\mathrm{P} 2$ & P3 & P4 & P5 & P6 & P7 & P8 \\
\hline \multirow{6}{*}{ Mundaú Lagoon } & Mundaú River mean discharge $\left(\mathrm{m}^{3} / \mathrm{s}\right)$ & 31.17 & 23.55 & 12.31 & 4.09 & 66.24 & 26.92 & 20.68 & 40.02 \\
\hline & Inflow volume $\left(\mathrm{hm}^{3}\right)$ & -5.9454 & -6.1316 & -6.0105 & -6.1795 & -5.6602 & -6.0398 & -6.1425 & -6.1842 \\
\hline & Outflow volume $\left(\mathrm{hm}^{3}\right)$ & 6.5438 & 6.653 & 6.2399 & 6.1941 & 6.8281 & 6.6287 & 6.6021 & 7.1215 \\
\hline & Variation in volume $\left(\mathrm{hm}^{3}\right)$ & 0.5984 & 0.5214 & 0.2294 & 0.0146 & 1.1679 & 0.5889 & 0.4596 & 0.9373 \\
\hline & Lagoon volume $\left(\mathrm{hm}^{3}\right)$ & 41.650 & 41.650 & 39.000 & 39.000 & 44.300 & 44.300 & 41.650 & 41.650 \\
\hline & Residence time scale (days) & 9.43 & 10.93 & 13.90 & 18.19 & 6.02 & 10.87 & 11.68 & 7.93 \\
\hline \multirow{6}{*}{ Manguaba Lagoon } & Paraíba do Meio River mean discharge $\left(\mathrm{m}^{3} / \mathrm{s}\right)$ & 21.27 & 17.28 & 8.48 & 3.01 & 47.6 & 14.13 & 12.38 & 40.07 \\
\hline & Inflow volume $\left(\mathrm{hm}^{3}\right)$ & -1.3098 & -1.772 & -1.4416 & -1.8318 & -0.9821 & -1.7703 & -1.4797 & -1.7423 \\
\hline & Outflow volume $\left(\mathrm{hm}^{3}\right)$ & 2.1506 & 2.1815 & 1.5894 & 1.5281 & 3.1779 & 2.0892 & 1.8843 & 2.9058 \\
\hline & Variation in volume $\left(\mathrm{hm}^{3}\right)$ & 0.8408 & 0.4095 & 0.1478 & -0.3037 & 2.1958 & 0.3189 & 0.4046 & 1.1635 \\
\hline & Lagoon volume $\left(\mathrm{hm}^{3}\right)$ & 101.100 & 101.100 & 97.500 & 97.500 & 104.700 & 104.700 & 101.100 & 101.100 \\
\hline & Residence time scale (days) & 45.59 & 50.38 & 84.74 & 123.26 & 23.81 & 60.38 & 67.47 & 25.48 \\
\hline
\end{tabular}

Figure 7 shows the residence time (RT) isolines for periods 1 and 2 in the CELMM, indicating different values in the lagoons. In the region near the inlets and in the channels, residence time was low and less than 10 days; in this region there was a relative water mass exchange, favoring effluent transport and dispersion. In the back area of the lagoon, residence time is high, with a significant spatial variation. This variation can be used to define three compartments: the back area of the lagoons, with RT values between 60 and more than 365 days; an intermediate region, with RT between 20 and 60 days; and the region near the inlet, with low RT values, between a few hours and 20 days. In some meanders, mainly in the channels, RT is higher, and these regions can be identified as possible stagnation areas.

The spatial isoline RT function patterns are similar in the two periods. However, in period 2, RT values are higher, primarily in the lagoons. This behavior is associated with freshwater discharge. In period 1, which exhibits an average of wind and river discharge data, the freshwater discharges were always other than zero, with a continuous water supply, not exhibiting large variations, or peaks, which are favorable to the advective process. In period 2, with wind and river discharge data from 2014, fresh water discharges were sometimes very low, with a number of significant peaks (see Figure 2) causing a jet effect, but only in the regions near the mouth of the rivers.

For environmental management purposes, it is important to identify stagnant areas in water bodies since they are potentially susceptible to pollutant accumulation. The RT results, analyzed in conjunction with the location of the particles at the end of the simulation (see Figure 7) and the regions where they are absorbed, may indicate areas prone to pollutant accumulation and higher concentrations of dissolved substances in the water mass. Note that the back area of the lagoons also contains particles, and RT is equal to 365 days. This means that the particles that were initially in that region remain in the lagoons' domain. In these areas, RT must be longer than 365 days. 


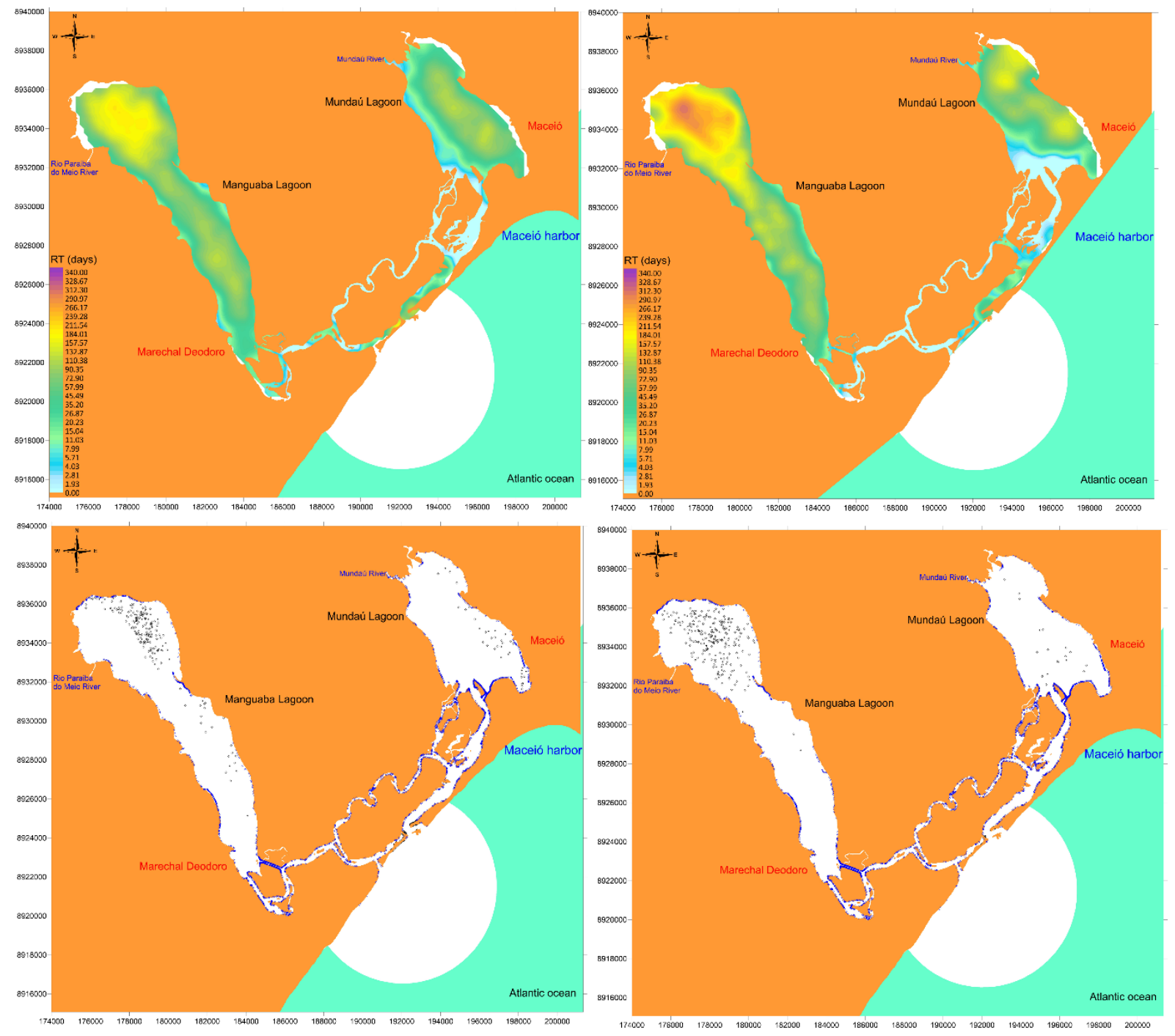

Figure 7. Isolines of Residence Time and the particle position for the end of the 365-day simulation for period 1 (left) and period 2 (right). The blue areas represent the regions where the particles were absorbed.

In the adjacent coastal region, the largest number of absorbed particles is found on the South coast. In the two periods, the prevailing wind is from the East, explaining why the right margins of the lagoons receive the largest number of absorbed particles. Lagoon alignment shows that the SouthEast wind has a greater influence on hydrodynamics than the East wind. However, the East wind generates a set-up on the right margin of the lagoons, generating pressure gradients that change the circulation and spatial distribution of residence time isolines.

For a simulation of the current situation of the lagoons, it would be necessary to update the bathymetry and inlet channel configuration, which shifts positions dynamically. These changes, possibly, should alter the circulation and, consequently, the water renewal processes in the channels that connect the lagoons with the adjacent coastal region, but will have little effect on the lagoons. Therefore, it seems plausible to affirm that the conclusions regarding circulation and water renewal processes in the lagoons would be valid for current scenarios, considering that this study used river discharge representative of the seasonal variations in the region.

\subsection{Salinity and temperature}

The results for the salt and heat transport presented in this section demonstrate that salt enters the channels readily and how river discharge variations affect the transport of salt and heat within the lagoons. Figure 8 illustrates the variations in salinity for periods 1 and 2 and the 
freshwater discharges used in each simulation. In period 1, with average river discharge data, one can notice that the salinity oscillates with the tides in the dry period in the lagoons, with a decreasing trend at the beginning of the rainy season. Similar behavior occurred in the coastal region, with salinity values of around $30.0 \mathrm{psu}$. In the rainy period, salinity declined in the lagoons, reaching zero, approaching the boundary condition imposed by the rivers. At the end of the rainy season, salinity increased when flows declined, with a rapid rise, mainly in the Manguaba Lagoon. The coastal region has significantly lower salinity, caused by the entry of fresh water from rivers.
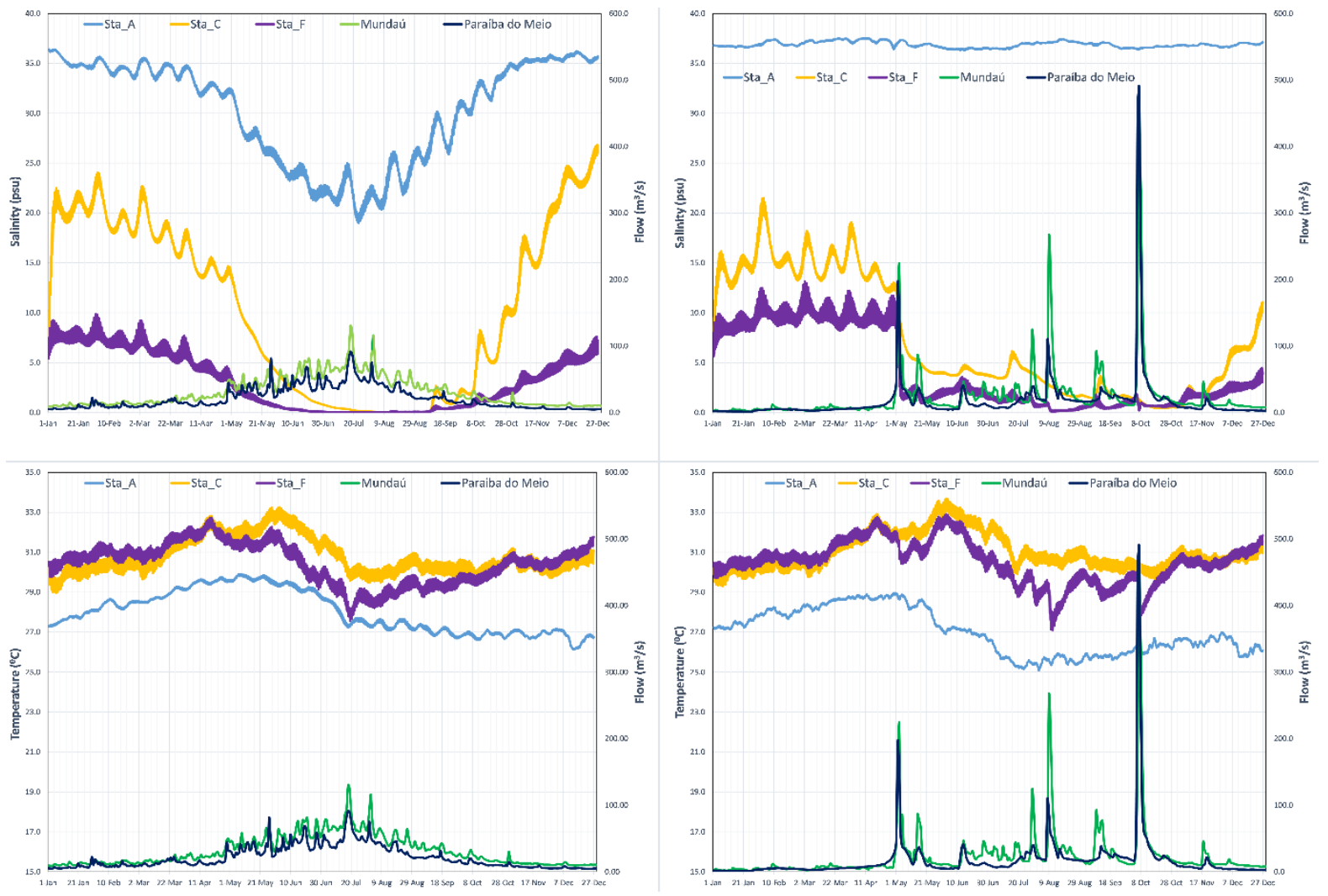

Figure 8. Salinity and temperature values obtained numerically by SisBAHIA ${ }^{\circledR}$ for period 1 (left) and period 2 (right) and discharges of the Mundaú and Paraíba do Meio Rivers.

In period 2, for the river discharge data from 2014, the dry season salinity remained stable in the lagoons, due to the very low fresh water supply from the rivers. However, in early May, a significant flow event caused a considerable decline in the salinity values of the lagoons. In the rainy season, the intermittency of flow rates resulted in a variation in salinity values but maintaining salinity below 5.0 in the lagoons. The salinity values only recovered in October after that extreme flow event. The adjacent coastal region was not affected by flow rate variations, maintaining salinity above 35.0.

Figure 8 shows the temperature variations for periods 1 and 2 . Since the water in the rivers is warmer in the dry season (around $35^{\circ} \mathrm{C}$ ) and cooler in the rainy period (around $27^{\circ} \mathrm{C}$ ), temperatures rise in the dry period and decrease in the rainy season in the lagoons. The flow data from 2014 reveal three significant drops in temperature in the Mundaú Lagoon in May, August, and October, corresponding to peak flows and the entry of cooler water from the rivers. The average flows exhibit similar behavior, but since the peak flows were mitigated, the decline in temperature was also smaller. The temperature values in the coastal region were influenced by freshwater discharge variations but did not show great variations. 


\section{CONCLUSIONS}

In this paper, the effects of the variations in river discharge and wind on the circulation, water renewal, salinity and the temperature of the CELMM were analyzed. In back areas of the lagoons, the results provided by the circulation model clearly show the influence of river inflows in the water renewal and hydrodynamic circulation. However, in Mundaú Lagoon, the region near the inlet is dominated by the tides; in the Manguaba Lagoon, the tides are very small and circulation and transport are also determined by the wind. In the channels that connect the lagoons with the adjacent coastal region, the tide is the most important forcing of circulation. The lagoons exhibited a predominance of ebb currents; the balance between the inflow (negative) and the outflow volumes (positive) was nearly always positive, except in the Manguaba Lagoon and during the dry season, when the freshwater discharge is lower. The rest of the time there is a tendency for water to be exported, favoring the transport of dissolved substances beyond the lagoons.

With respect to absorption in the Manguaba and Mundaú Lagoons, the tidal range was around $90 \%$ and $80 \%$ lower, respectively, when compared to the adjacent coastal region, indicating a severe head load along the channels.

The transport of dissolved substances and the water turnover capacity inside the lagoons may be associated with residual circulation, affected by different temporal and spatial scales, as the advective and diffusive transport of neutral particles may be related to the dispersion of passive and conservative substances dissolved in the water. In the present study, two methodologies were used to investigate the water turnover in the lagoons: the first, more simplified, assumes that the system is in permanent regime, well mixed and with small fresh water discharge compared to the tidal prism, whereas the second methodology employs a Lagrangian transport model, which makes it possible to determine the residence time isolines. The average RT calculated by the simplified model ranged from 23 to 123 days for the Manguaba Lagoon and 6 to 18 days for the Mundaú Lagoon. A comparison of these results with those obtained with residence time isolines, which determined RT ranging between 11 and more than 365 days for the Manguaba Lagoon and from 2 to 180 days for Mundaú, demonstrated that the simplifications used in the first methodology are not adequate. Given the spatial heterogeneity in the system, the models are more indicated to determine isolines, since they make it possible to identify which inner regions of the lagoons are critical for substance accumulation, that is, with longer residence times. After one year of simulation, the back area of the lagoons still contained particles, that is, long residence times. The margins of the lagoons and channels exhibited absorbed particles, that is, the tendency to retain dissolved particles.

The results of the model show a prolonged period with low salinity and a slow recovery after the rainy period. It also shows that high freshwater discharge in the Mundaú and Paraíba do Meio Rivers, the main tributaries of the CELMM, which occurred in May, August, and October 2014, caused a sharp drop in salinity. The salinity values increase in the dry periods, confirming the high dependence of spatial variations with freshwater discharge, that is, variations in salinity are controlled primarily by river discharge and, to a lesser degree, the by tides. When a significant discharge occurs in the rivers, salinity decreases rapidly inside the lagoons. The channels show that salinity exhibited typical tidal oscillations. Water temperature displayed little spatial and temporal variation, with a slight decrease in temperature during the rainy season and a rise in the dry period. Events with significant river discharges also lowered the temperature, although less than salinity.

The investigation concerning the CELMM responses to an extreme event, with high freshwater discharge in October 2014, showed a reduction in the residence time scale in both lagoons, showing that river discharge has an important effect on water mass exchanges between the lagoons and the adjacent coastal region, significantly changing the salinity values in the 
lagoons and in the channels, resulting in null values at some time intervals.

The conclusions presented here, in conjunction with other studies conducted for the region, can be used to establish strategies for the use of lagoon waters as a mollusk, crustacean and fish breeding ground, thereby minimizing the impacts of anthropic activities, and maintaining fishing- and tourism-related endeavors.

\section{ACKNOWLEDGEMENTS}

The study was supported by the Coordenação de Aperfeiçoamento de Pessoal de Nível Superior - Brasil (CAPES) - Procad 2013.

\section{REFERENCES}

AGUILERA, L.; SANTOS, A. L. F. Dos; ROSMAN, P. C. C. On characteristic hydraulic times through hydrodynamic modelling: discussion and application in Patos Lagoon (RS). Revista Ambiente \& Água, v. 15, p. e2456, 2020. http://dx.doi.org/10.4136/ambiagua. 2456

ALVES, M. C. Composição e Acumulação da matéria Orgânica (C, N, Ligninas) nos sedimentos do sistema Lagunar Mundaú-Manguaba. 2010. 98f. Dissertação (Mestrado em Geociências - Geoquímica Ambiental) - Universidade Federal Fluminense, Niterói, 2010.

ANA (Brasil). Plano de ações e gestão integrada do Complexo Estuarinolagunar Mundaú/Manguaba (CELMM). Brasília, 2006. 112 p.

ANA (Brasil). Hidroweb platform: Sistemas de informações hidrológicas. Available at: http://www.snirh.gov.br/hidroweb/. Access: May. 2019.

BRITO, A. N.; FRAGOSO, C. R.; LARSON, M. Tidal exchange a choked coastal lagoon: a study of Mindaú Lagoon in northeastern Brazil. Regional Studies in Marine Science, v.7, p. 133-142, 2018. http://dx.doi.org/10.1016/j.rsma.2017.12.005

CUNHA, C. L. N.; CORREA, G. P.; ROSMAN, P. C. C. A coupled model of hydrodynamics circulation and water quality applied to the Rio Verde reservoir, Brazil. Revista Ambiente \& Água, v. 13, p. e2244, 2018. https://doi.org/10.4136/ambi-agua.2244

DE LIMA, A. C. C. Condições Hidrodinâmica e estimativas do tempo de residência no Complexo Estuarino Lagunar Mundaú/Manguaba (AL) através de modelagem computacional. 2017. 102 f. Dissertação (Mestrado em Meteorologia) - Instituto de Ciências Atmosféricas - Universidade Federal de Alagoas, Maceió, 2017.

FEMAR. Catálogo de Estações Maregráficas Brasileiras. Rio de Janeiro, 2009.

GONZÁLES-GORBEÑA, E.; ROSMAN, P. C. C.; QASSIM, R. Y. Assessment of the tidal current energy resource in São Marcos Bay, Brazil. Journal of Ocean Engineering and Marine Energy, v. 1, p. 421-433, 2015. https://doi.org/10.1007/s40722-015-0031-5

INMET. Dados Meteorológicos. Available at: https://tempo.inmet.gov.br/TabelaEstacoes/82994\#/. Access: May. 2019.

KIM, C.; PARK, K. A modeling study of water and salt exchange for a micro-tidal, stratified northern Gulf of Mexico estuary. Journal of Marine Systems, v. 96-97, p. 103-115, 2012. https://doi.org/10.1016/j.jmarsys.2012.02.008 
LI, Y.; YAO, J. Estimation of Transport Trajectory and Residence Time in Large River-Lake Systems: Application to Poyang Lake (China) Using a Combined Model Approach. Water, v. 7, p. 5203-5223, 2015. https://doi.org/10.3390/w7105203

MAHANTY, M. M.; MOHANTY, P. K.; PATTNAIK, A. K.; PANDA, U. S.; PRADHAN, S.; SAMAL, R. N. Hydrodynamics, temperature/salinity variability and residence time in the Chilika lagoon during dry and wet period: Measurement and modelling. Continental Shelf Research, v. 125, p. 28-43, 2016. https://doi.org/10.1016/j.csr.2016.06.017

MIRANDA, L. B.; CASTRO, B. M.; KJERFVE, B. Princípio de Oceanografia Física de Estuários. São Paulo: Editora da Universidade de São Paulo, 2002. 425p.

OLIVEIRA, A. M.; KJERFVE, B. Environmental Response of a Tropical Lagoon System to Hydrological Variability: Mundaú-Manguaba, Brazil. Estuarine. Coastal and Shelf Science, v. 37, p. 575-591, 1993. https://doi.org/10.1006/ecss.1993.1074

PANDA, U. S.; MAHANTY, M. M.; RANGA RAO, V.; PATRA, S.; MISHRA, P. Hydrodynamics and water quality in Chilika Lagoon-A modelling approach. Procedia Engineering, v. 116, p. 639-646, 2015. https://doi.org/10.1016/j.proeng.2015.08.337

PEREIRA-BARROS, J. B. Bibliografia comentada sobre o sururu Mytella falcata e a bioecologia do complexo estuarino Mundaú-Manguaba, AL. Parte I. Boletim de Estudos de Ciências do Mar, n 6, p. 36-48, 1987.

ROSMAN, P. C. C. Referência Técnica do SisBaHiA ${ }^{\circledR}$. Rio de Janeiro: Fundação Coppetec; COPPE, 2019.

SILVA, C. S. Distribuição e abundância da fauna macrobentônica do complexo estuarino Mundaú/Manguaba (Alagoas-Brasil). Boletim de Estudos de Ciências do Mar, v. 8, p. 45-64, 1994.

SOUZA, R. C.; REIS, R. S.; FRAGOSO JUNIOR, C. R.; SOUZA, C. F. Uma análise na Dragagem do Complexo Estuarino-Lagunar Mundaú/Manguaba em Alagoas através de um Modelo Numérico Hidrodinâmico Bidimensional-Resultados Preliminares. Revista Brasileira de Recurso Hídricos, v. 9, p. 21 - 31, 2004. https://doi.org/10.21168/rbrh.v9n4.p21-31

TEIXEIRA, R. L.; SÁ, H. S. Abundância de macrocrustáceos decápodas nas áreas rasas do complexo lagunar Mundaú/Manguaba, AL. Revista Brasileira de Biologia, v. 58, p. 393-404, 1998. https://doi.org/10.1590/S0034-71081998000300005

WALLCRAFT, A. J.; METZGER, E. J.; CARROLL, S. N. Design Description for the Hybrid Coordinate Ocean Model (HYCOM) Version 2.2. Naval Research Laboratory. Condado de Hancock: Stennins Space Center, 2009. Technical Report. 